\title{
DEFINING SOCIAL INNOVATION: THEORETICAL DISCOURSE
}

Svetlana Polovko', Mg.oec.; Gunta Grīnberga-Zālīte², Dr.oec., assoc.prof.

1,2Latvia University of Life Sciences and Technologies

Annotation. Although the scope of the theoretical discourse on business innovation today is remarkable and still growing, its off-spring "social innovation" is yet only in the process of formation. Gone are those days when economically advanced European Union countries made every effort to enhancing business innovation in their national economy sectors. Nowadays, even the most successful EU Member States show increasing interest in developing such innovation products that could overcome the failure of the existing national economy models to handle increasing social problems caused by regional disparities, social inequality, availability of primary and secondary education and health care. Latvia is one of those EU Member States, which still is exposed to uneven economic development and its caused social consequences such as unemployment, social exclusion, unavailability of social services in the regions. The intention of the authors is to explore the potential of target-oriented social innovation creation in Latvia regions to eliminate their disparities. In this respect, the authors consider that before conducting so specific research, it is first of all necessary to summarize the existing definitions of social innovation and, based on them, formulate a new, specially designed definition that would most precisely comply with and could be used in the context of regional development studies. The study uses monographic method, methods of analysis and synthesis, method of scientific induction and scientific deduction. In scope of the research, the authors have clarified the narrow and broad context of social innovation concept and have formulated a new definition, which will be used in the further authors' research devoted to regional development studies.

Key words: social change, social problems, innovation.

JEL code: O35, O31.

\section{Introduction}

Activities related to promoting social innovation are increasingly included in the European Union regulatory enactments and development plans. It is emphasized that social innovation is a powerful tool for addressing social problems. However, the studies of scientific literature reveal the lack of unified and over-embracing approach to the issues related to the definition of social innovation. Therefore, this study is devoted to the analysis of the existing theoretical framework of social innovation.

The aim of the study is to analyse the concepts "innovation" and "social innovation". In the study, the authors used the following methods: monographic method (to analyse theoretical literature sources and interpret various definitions); methods of analysis and synthesis to study the elements of the problem separately and to establish mutual relations; scientific induction method - to create scientific assumptions and similarities based on individual elements; scientific deduction method logically systematize and explain empirical data. Within the framework of the study, the authors used scientific literature on evolution of innovation concept. The aim of the research is to analyse the theoretical discourse of social innovation concept. The specific research tasks are: 1) to clarify the common and different features of "innovation" and its off-spring "social innovation"; 2) to study and interpret the existing theoretical definitions of social innovation; 3 ) to formulate the definition that could be used in the further author's research to explore the potential of target-oriented social innovation creation in Latvia regions to eliminate their disparities The object of the current research is social innovation but the subject is theoretical discourse of social innovation definition.

\footnotetext{
${ }^{1}$ Email: svetlana.polovko@inbox.lv, mob. +37125944741

2 Email: gunta.grinberga@llu.Iv, mob. +371 29463545
} 


\section{Research results and discussion}

There is a growing demand for innovative solutions to social problems in society. While great progress has been made thanks to technology and advanced social services, yet every improvement brings new challenges and, accordingly, new problems. Nevertheless, critical societal challenges can also become opportunities with an active involvement of community actors. Since 2009, social innovation initiatives have been discussed at the European Commission, whereby social innovation has been associated with a contemporary and efficient solution for solving increasing numbers of various social needs. The economic crisis is seen as a motivating factor for the development of innovative solutions, while also promoting the exploitation of the society's own development potential. Also, the authors' previous research (Grinberga-Zalite, Oganisjana, Surikova, 2015) related with exploring different aspects of social innovation's dimensions gives evidence of social innovation's potential to deal with problems that existing institutional and political framework failed to address, e.g. climate change or increasing inequality.

\section{The essence and development of innovation and social innovation}

The concept of innovation was first introduced at the end of the 12th century in France, it was used in conversational language and denoted the ability of a person to invent something new.

In scientific society this term was first mentioned in the 19th century, when it meant the process of cultural diffusion, which involves the inclusion of elements of one culture in another culture.

In the beginning of the 20th century, the term "innovation" appeared in the work of economists and sociologists (G.Tard, N.Kondratjev, J.Schumpeter) who had found a link between innovation and the dynamic development of society.

Today it is believed that Schumpeter is the founder of innovation theory who in 1912 in his Theory of Economic Development argued that "innovation is any possible change based on the creation of a new value method, entry into a new market or use of a new source of raw materials". Thus, innovation is characterized not only by the invention, but also by the process by which the invention is realized. In the course of time, Schumpeter (1964) defined innovation as a combination of new elements (inventing new goods, methods, raw materials into an organization or industry), which is a novelty to the existing economic system. In Latvia, the term "innovation" was first introduced in the Dictionary of Foreign Words (1996) and was explained as "novelty" and "novation".

The discourse of modern science and philosophy due to digitalization of economy and society has caused a rather ambiguous understanding of innovation. Moreover, the absence of a generally accepted innovation theory leads to the growing numbers of various innovation definitions, which often contributes to the change of the essence of this term. Accordingly, today in the theory two innovation positions are denoted - innovation-process and innovation-result.

The first position is clearly-defined in the definition of Hungarian researcher B. Santo "innovation - is a socio-technical-economic process that leads to a better product or technology through the practical use of ideas and inventions". Whereas the second position is explained by Crozier and Friedberg, arguing that "innovation is a process of collective creation in which members of a collective entity learn, invent and develop new products, technologies and forms." The innovation definition that has been adopted in Latvia also refers to the process "Innovation is a process where (...)".

The term "social innovation" is relatively new, but the concept of social innovation itself has already existed long before, for example, when various social institutions emerged, shelters for poor people were established, and the emergence of cooperatives is also an example of social innovation. 
Although there are still different opinions and discussions on the definition of the term "social innovation", it is gradually gaining more prominence in the discussions on EU policy priorities. While working on the Europe 2020 strategy, the term "social innovation" was used with great caution, but it is now present in almost all discussions on the formulation of smart and inclusive growth priorities and the possibilities to achieve them. Given the current emphasis on the need to seek new ideas to address societal needs, social innovation is gradually taking root in the operational programmes of the EU and its Member States.

The academic interest in social innovation began in the 60 s of the 19 th century. Academic literature provides a broad approach to conceptually defining social innovation's concept. The first researcher of the 19th century who used social innovation's concept was Webber, who used it to designate a social invention.

However, social innovation themes and concepts had existed long before. Mr. Franklin said that minor changes in the work of social organizations can solve many of the daily social problems. Many of the 19th century researchers, such as Mr Ouens, Mr Weber and Mr Marx, promoted their ideas for social innovation and anticipating profound social change. Later, several attempts were made to structure the field of social innovation, such as Moulaert and Nussbaumer (2005), Pol and Ville (2009), and Dobele (2015). However, the literature studies give evidence that often all these categories lack systematic methodologies that simultaneously incorporate the concept of social innovation in different disciplines.

Nowadays, the idea of social innovation has become a vector of political-economic development of modern developed countries, and their origins date back to the 1990s, when the initiatives of the European Social Fund - NOW, ADAPT, HORIZ ON, LEADER - became the basis of a new approach to social policy making, breaking down borders between the state, the private sphere and civil society.

In the EU Innovation Union, special attention is paid to social innovation. The Innovation Union explains the term "social innovation" as an opportunity to involve EU citizens in economic activities. The "Innovation Union” initiative encourages Member States to use the European Social Fund for investment in social innovation projects. Social innovation projects are often viewed in paralel with the aspiration to reduce poverty at the European level. The Innovation Union's initiative stresses the need to enhance the support for social innovation measures in 2014-2020 and calls on the Member States to be more active in supporting social innovation projects. Social enterprises are also seen as an option how to improve the access for women and young people to the labour market, and to support other categories of disadvantaged workers.

Officially, the idea of social innovation was recognized in 2010, in the meeting of Z.M. Barroso and public activists and innovators, which led to the inclusion of concrete proposals in the Europe 2020 strategy.

The distinction between the concepts of "innovation" and "social innovation" is complicated because of the fact that science has a narrow and broad understanding of the term "social". In a broad sense, "social" is similar to the public and opposed to natural and biological factors. In a narrow sense, "social" is related to the sociological, linked to social, i.e. human relationships as members of particular social groups. Consequently, social innovation in a narrow and broad sense differs. In a broad sense, all kinds of innovation can be considered as social: technotechnological, economic, political, psychological, scientific, ecological, cultural etc., because they are

${ }^{1}$ The Innovation Union is one of the seven flagship initiatives of the EU 2020 strategy developed by the European Commission to identify national, European and international actions to be implemented in the field of innovation in order to achieve the goals of the EU 2020 strategy. 
social phenomena and are attributed to the defined sphere of public life. Whereas in the narrow sense, social innovation is understood only as a change in the social sphere of society that leads to changes in social groups, their relationships, changes in social environment, social institutes and organizations.

In the scientific literature, the innovation is generally associated with changes (according to J. Schumpeter). But, in the authors' opinion, such an understanding is not fully correct and changes its nature, because innovation rather commits changes, but it is not a change itself. Accordingly, innovation and change - these are related processes, but not identical.

Table 1

\section{The discourse of social innovation concepts}

\begin{tabular}{|c|c|}
\hline Definition & Authors \\
\hline $\begin{array}{l}\text { "The commitment of an individual or group to take responsibility for a social need or a } \\
\text { set of social needs that are not satisfied" }\end{array}$ & Chambon et.al. (1982, p. 8) \\
\hline $\begin{array}{l}\text { "The process of collective creation, in which certain members of a collective entity learn, } \\
\text { invent and develop new rules for cooperation and social conflict situation, or, in other } \\
\text { words, new social practices, and in this process they acquire the necessary cognitive, } \\
\text { rational and organizational skills" }\end{array}$ & $\begin{array}{l}\text { Crozier \& Friedberg }(1993, \\
\text { p.19) }\end{array}$ \\
\hline "Creating and implementing new ideas about social relations and social organisation" & Mumford (2002, p.253.) \\
\hline $\begin{array}{l}\text { "New organizational and institutional forms, new ways to act, new social practices, new } \\
\text { mechanisms, new approaches and new concepts that bring specific achievements and } \\
\text { improvements" }\end{array}$ & $\begin{array}{l}\text { Centre de Recherche sur les } \\
\text { Innovations Sociales } \\
\text { (CRISES, 2004) }\end{array}$ \\
\hline $\begin{array}{l}\text { "New forms of social relations, including institutional and organizational innovations, new } \\
\text { forms of production and consumption, and new relationships between economic and } \\
\text { social development" }\end{array}$ & $\begin{array}{l}\text { Neamtan un Downing } \\
(2005, \text { p.12) }\end{array}$ \\
\hline $\begin{array}{l}\text { "Social innovation at local level is based on two pillars: institutional innovation } \\
\text { (innovation in social relations, innovation in innovation dynamics) and innovation in the } \\
\text { social economy, i.e. meeting the diverse needs of local communities" }\end{array}$ & $\begin{array}{l}\text { Moulaert un Nussbaumer } \\
(2005, \text { p. 2071) }\end{array}$ \\
\hline "Providing innovation services in institutional forms" & $\begin{array}{l}\text { Gerometta et al., 2005; } \\
\text { Gallie et al., } 2012\end{array}$ \\
\hline $\begin{array}{l}\text { "Innovative activities and services based on the goal of meeting social needs and } \\
\text { distributed primarily through organizations" }\end{array}$ & Mulgan $(2006$, p. 146) \\
\hline $\begin{array}{l}\text { "Changes in society's cultural, regulatory enactments or regulatory structures that } \\
\text { improve its collective energy resources and improve its economic and social } \\
\text { performance" }\end{array}$ & Heiskala (2007, p. 59) \\
\hline $\begin{array}{l}\text { "Innovations outside national or market organizations; in the social, charitable, } \\
\text { voluntary, community sectors" }\end{array}$ & $\begin{array}{l}\text { Haugh \& Kitson, (2007, } \\
\text { p. 975) }\end{array}$ \\
\hline "Experiments for providing social services in socially excluded groups" & Phills et al., (2008, p.45) \\
\hline "Social innovation - a new social practice with social goals and social means to achieve it" & Franz et al., (2012) \\
\hline $\begin{array}{l}\text { "Social innovation is the development and introduction of new ideas (products, services) } \\
\text { to meet social needs and to create new social relationships and cooperation. Social } \\
\text { innovation sets social goals and uses social means to achieve them " }\end{array}$ & $\begin{array}{l}\text { Guide to Social innovation. } \\
\text { European Commission, } \\
2013\end{array}$ \\
\hline $\begin{array}{l}\text { "Social innovation is innovation that is associated with social aspects both in terms of } \\
\text { their purpose and their means, and in particular those relating to development and } \\
\text { realization of new ideas which at the same time meet social needs and build new social } \\
\text { relationships or expressions of cooperation, thus benefiting society and promoting its } \\
\text { ability to act. " }\end{array}$ & $\begin{array}{l}\text { Regulation of the European } \\
\text { Parliament and the Council } \\
\text { (EU) No. 1296/2013 } \\
(11.12 .2013)\end{array}$ \\
\hline
\end{tabular}

Source: created by the author based on theoretical literature studies

Due to its specificity, social innovation not only introduces constructive changes in society, but also causes unexpected side-effects with a high degree of risk and uncertainty, escalation of conflicts and contradictions. Sometimes the magnitude of these side-effects may be greater than the effect of social innovation itself, which may change the expected outcome.

Consequently, social innovation can be interpreted as a complex social process in which new elements are introduced and integrated into different spheres of society, resulting in significant and irreversible changes in the sphere of social relations. On the one hand, this process contributes to positive change in society, actively develops new social ties and relationships, new spiritual and 
intellectual needs. But on the other hand, it can lead to a variety of destructive phenomena: social tensions, technological breakdown, conflicts, social protests etc., thus undermining the order in society.

Based on theoretical literature studies, the author has defined social innovation as "a new, sustainable and effective solution to address societal social problems and improve living standards".

The literature studies also revealed that there are two types of social innovation:

1) social novation - social innovation that has been created but not yet implemented;

2) social innovation - innovation in the social sphere that has been implemented (Hubert et al. 2010; Murray, Caulier-Grice \& Mulgan, G., 2010).

The social sphere covers the entire sphere of human life - from human lifestyles, work, health and leisure and ending with socio-ethnic relations and climate change on our planet.

The multidisciplinary theoretical research on social innovation provides a number of interrelated concepts, such as follow:

- social system (Westley, Antadze, Riddell, Robinson, \& Geobey, 2014; Cajaiba-Santana, 2013);

- social value (Minks, 2011);

- social (societal needs) (Heller, 2014);

- social problems (Minks, 2011);

- social challenges (The Young Foundation, 2012a);

- social impact (Ortega, Furr, Liman, \& Flint, 2014);

- social change/societal transformation (Cajaiba-Santana, 2013; Minks, 2011; OECD, 2010; Westley, Antadze, Riddell, Robinson, \& Geobey, 2014);

- social quality (Li, Sun, \& Lin, 2012);

- quality of life (Pol \& Ville, 2009; Li, Sun, \& Lin, 2012; OECD, 2010);

- quantity of life (Pol \& Ville, 2009).

Accordingly, social innovations can be attributed to:

- employment, income, living standards and quality of the population;

- health, demography, maternity and children;

- social protection and public safety;

- all forms and forms of education, culture and leisure;

- environmental protection (Hubert, et al., 2010; Murray, Caulier-Grice, \& Mulgan, 2010).

Since social innovation incorporates the social aspect, it helps to solve the problems of vulnerable groups of the population (such as the interests of children and young people, the elderly, the disabled, the poor, large families, refugees, etc.).

\section{Conclusions, proposals, recommendations}

1) The study of the theoretical framework of social innovation revealed that it is possible to distinguish a narrow and broad context of social innovation, which significantly differ. In a broad sense, all kinds of innovation can be considered as social: technological, economic, political, psychological, scientific, ecological, cultural etc., because they are social phenomena and are attributed to the defined sphere of public life. Whereas in the narrow sense, social innovation is understood only as a change in the social sphere of society that leads to changes in social groups, their relationships, changes in social environment, social institutes and organizations.

2) Alongside with the changes in society, its values and needs as well as owing to technological progress, the concept of social innovation is constantly adjusting to the new encountered 
situations. Accordingly, academicians and innovation policy makers have to keep up with socioeconomic changes and update the existing definitions with new refinements, especially related with the emergence of new ICT.

3) Based on the analysis of the existing definitions, the author has developed a new definition of social innovation "a new, sustainable and effective solution to address societal social problems and improve living standards", which particularly complies with current social problems of Latvia and thus could be applied in the research works related with regional disparity analysis.

\section{Bibliography}

1. Cajaiba-Santana, G. (2013). Social Innovation: Moving the Field Forward. A Conceptual Framework. Technological Forecasting and Social Change, p. 82, pp. 42-51.

2. Centre de Recherche sur les Innovations Sociales (2004) CRISES Rapport annuel des activities du CRISES, Quebec.

3. Chalmers, D. (2012). Social Innovation: An Exploration of the Barriers Faced by Innovating Organizations in the Social Economy. Local Economy, 28(1), pp. 17-34.

4. Chambon, J.-L., David, A., and Devevey, J-M., (1982) Les innovation sociales, Paris: Presses Universitaires de France.

5. Crozier, M., Friedberg, E. (1993). Die Zwange kollektiven Handelns - Uber Macht und Organization, Frankfurt/M.\&Hain, Beltz Athenaum

6. Dobele, L. (2013). Social Entrepreneurship Development Possibilities in Latvia. Doctoral Thesis. Retrieved from http://llufb.llu.Iv/dissertationummary/entrepreneurship/LasmaDobele_promoc_d_kopsavilkums_2014_LLU_ESAF. Access: 12.12.2018.

7. European Commission (2012). Strengthening Social Innovation in Europe. Journey to Effective Assessment and Metrics. Retrieved from http://ec.europa.eu/enterprise/policies/innovation/files/socialinnovation/strengthening-social-innovation_en.pdf. Access: 12.12.2018.

8. European Commission. (2013). Guide to Social Innovation. Retrieved from http://ec.europa.eu/regional_policy/sources/docgener/presenta/social_innovation/social_innovation_2013.p df. Access: 12.12.2018.

9. Franz, H.W., Sarcina, R., Jurgen H. (2012) Facilitation social innovation and cluster development. pp. 24-29.

10. Grinberga-Zalite, G., Oganisjana, K., Surikova, S. (2015). The Study of Social Innovation Theoretical Framework for Enhancing of Rural Development and Agriculture in Latvia. Proceedings of the International Scientific Conference "Economic Science for Rural Development", Latvia University of Agriculture. Jelgava, 2015. No. 40: Marketing and sustainable consumption. New dimensions in the development of society, pp. 205-215.

11. Haugh, H., Kitson, M., (2007), The Third Way and the Third Sector: New Labour's economic policy and the social economy. Cambridge Journal of Economics, 31 (6), pp.973-974.

12. Heiskala, R., (2007). Social innovations: Structural and power perspectives. In T. J. Hamalainen \&R. Heiskala (Eds.), Social Innovations, institutional change and economic performance. Cheltenham: Elgar.

13. Heller, C. (2014). The social innovation revolution. Print, 68(3), 40-43.

14. Hubert, A. et al. (2011). Empowering People, Driving Change: Social Innovation in the European Union. Bureau of the European Policy Advisers, European Commission.

15. Li, Y.; Sun, Y.; Lin, K. (2012). Social Innovation, Local Governance and Social Quality: The Case of Intersectoral Collaboration in Hangzhou City. International Journal of Social Quality, 2(1), pp.56-73.

16. Minks, M. (2011). Social Innovation: New Solutions to Social Problems. A Thesis submitted to the Faculty of The School of Continuing Studies and of The Graduate School of Arts and Sciences in partial fulfillment of the requirements for the degree of Master of Arts in Liberal Studies.

17. Moulaert, F., Nussbauner J., Defining the Social Economy and its Governance at the Neighbourhood Level: A Metodological Reflection, Urban Studies, 42(11), pp.2071-2088.

18. Mulgan, G., Tucker, S., Ali, R., Sanders, B. (2006). Social Innovation: What It Is, Why It Matters and How It Can Be Accelerated. Working Paper. London: The Young Foundation, The Basingstoke Press. pp. 27.

19. Mulgan, G., (2006) The process of social innovation. Innovations:Technology, Governance, Globalization, Vol. 1, No.2, pp. 145-162. MIT Press

20. Mumford, M.D. (2002). Social innovation: Ten cases from Benjamin Franklin. Creativity Research Journal, 14(2), pp.253-266.

21. Murray, R., Caulier-Grice, J., Mulgan, G. (2010). Ways to Design, Develop and Grow Social Innovation: The open book of social innovation. The Young Foundation \& NESTA. Retrieved from http://youngfoundation.org/wp-content/uploads/2012/10/The-Open-Book-of-Social-Innovationg.pdf. Access: 12.12 .2018 .

22. Neamtan, N., Downing, R (2005) Social economy and community economic development in Canada: Next steps for public policy. Issues paper by the Chantier de I'Economies Sociale in collaboration with the 
Canadian Community Economic Development Network (CCEDNet) and Alliance Recherche Universities Communautes en Economic Sociale (ARUC-ES)

23. OECD (2010). SMEs, Entrepreneurship and Innovation. Series: OECD Studies on SMEs and Entrepreneurship. OECD Publishing.

24. Ortega, S.; Furr, N.; Liman, E.; Flint, C. (2014). The Science of Social Impact Innovation: How to Deliver More Impact through Innovative Business Models. International Journal of Innovation Science, 6(2), pp.7382.

25. Phills, J.A., Jr., Deigmeier, K., Miller, D.N.(2008). Rediscovering social innovation. Stanford Social Innovation Review, Fall, pp.34-43

26. Pol, E.; Ville, S. (2009). Social innovation: Buzz word or enduring term? The Journal of Socio-Economics, 38(6), pp.878-885.

27. Santo B. (2009) A Positive Theory of Social Entrepreneurship. Journal of Business Ethics, Vol. 111, No. 3, pp. $335-351$.

28.Schumpeter, J. A., (1964): Theorie der wirtshaftlichen Entwicklung (6th ed.), Berlin: Duncker \&Humblot

29. The Young Foundation (2012a). Social Innovation Overview - Part I: Defining social innovation. A deliverable of the project: „The theoretical, empirical and policy foundations for building social innovation in Europe" (TEPSIE), European Commission - 7th Framework Programme, Brussels: European Commission, DG Research. Retrieved from

http://www.tepsie.eu/images/documents/TEPSIE.D1.1.Report.DefiningSocialInnovation.Part \%201 \%20- \% 20defining \%20social \%20innovation.pdf. Access: 24.12.2018.

30. Weber, M. (2012). Social Innovation and Social Enterprise in the Classroom: Frances Westley on Bringing Clarity and Rigor to Program Design. Academy of Management Learning \& Education, No. 11(3), pp. 409418.

31. Westley, F., Antadze, N, Riddell, D. J., Robinson, K., Geobey, S. (2014). Five Configurations for Scaling Up Social Innovation: Case Examples of Nonprofit Organizations From Canada. The Journal of Applied Behavioral Science, 50(3), pp.234-260. 